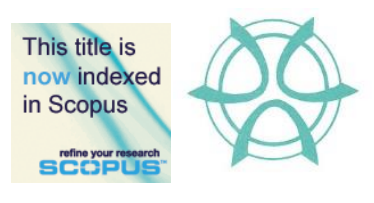

PLANNING MALAYSIA:

Journal of the Malaysian Institute of Planners

VOLUME 15 ISSUE 2 (2017), Page 51 - 66

\title{
SOCIAL IMPACT OF AGRO-TOURISM ON LOCAL URBAN RESIDENTS. CASE STUDY: CAMERON HIGHLANDS, MALAYSIA
}

\author{
Oliver Ling Hoon Leh ${ }^{1}$, Mohd Hafizol Che Mohd Noor ${ }^{2}$, Marlyana Azyyati \\ Marzukhi $^{3}, \&$ Siti Nur Afiqah Mohamed Musthafa ${ }^{4}$ \\ ${ }^{1,2,3,4}$ Faculty of Architecture, Planning and Surveying \\ UNIVERSITI TEKNOLOGI MARA (UITM)
}

\begin{abstract}
Agro-tourism is a new tourism product introduced in Malaysia based on agricultural attraction. Cameron Highlands is the largest agricultural based highland resort area in Malaysia. The cool climate, farms, and natural environment make Cameron Highlands a famous tourist destination. Agrotourism has become one of the important economic sectors in Cameron Highlands. The study is aimed to examine the social impact of the agro-tourism industry on the local urban residents in Cameron Highlands. A questionnaire survey was carried out among the local urban residents to examine the social impact based on the respondents' experience and perceptions. A sample of 100 respondents were selected from three main urban settlements in Cameron Highlands. The social impacts were analysed based on the changes over the period of five (5) years. The study covered four (4) main aspects, i.e. safety, job and business opportunity, migration, and social-cultural (language, religious and educational level). The findings indicate that the local urban residents were positively and also negatively affected by the agro-tourism activities and development in Cameron Highlands. Proper planning and policies are crucial to manage the agro-tourism and related development in Cameron Highlands.
\end{abstract}

Keywords: Agro-tourism, impact, migration, opportunity, social

Date Received: $26^{\text {th }}$ July 2016

Date of Acceptance: $6^{\text {th }}$ July 2017 
Oliver Ling Hoon Leh, Mohd Hafizol, Marlyana Azyyati, \& Siti Nur Afiqah

Social Impact of Agro-Tourism on Local Urban Residents. Case Study: Cameron Highlands, Malaysia

\section{INTRODUCTION}

The development of the tourism sector has become one of the important sources of economic growth in Malaysia and abroad (Athanasopoulou, 2013; Chou, 2013; Risso \& Brida, 2009). The growth of tourism sector also has a significant impact on the physical and social aspects of an area. Previously, tourism was mainly made up of travel, tours, fun and exploring the beauty of nature. But now, the agricultural activities and the farmland have also been marketed as tourism products. The agricultural activities are important for a country including Malaysia, in addressing food security, sustainability, and safety to ensure availability, affordability and accessibility of food (EPU, 2013). But agro-tourism can increase the economic return of a farmland and the agricultural industry. For instance, agro-tourism has been accepted as a new economic activity by the rural population in Poland (Wojciechowska, 2014).

One of the famous agro-tourism destinations in Malaysia is Cameron Highlands. However, the development of the tourism sector in the area has impacted the local residents. Cameron Highlands has been associated with several physical and social issues, such as environmental degradation, and the employment of foreign workers for agriculture and service industries (Sayed Idris, 2014). The influx of foreign workers potentially affecting the social values and cultural aspects of local residents.

In term of physical aspects, the rapid urban and agricultural development in Cameron Highlands has tarnished its natural environment, old-warm charm and historical values (Mohd Ariffin, et al., 2014). The tourism development has also contributed to traffic congestion at town areas due to narrow roads and illegal roadside parking (Manzor, 2009) especially during peak seasons. Besides, the use of fertilisers, pesticides and herbicides in farmlands is also polluting the environment.

Studies from abroad highlighted various positive and negative impacts of tourism development on local residents. For instance, impacts on job opportunities (employment), inflation, the rebirth of local arts and cultural activities, cultural change, migration, over-dependent on the tourism industry, and others (Lickorish, 1994; Mason, 1995; Mason, 2008; Pearce, 1987; Por, 2001; Burny, 2008). In Malaysia, a few studies have been carried out on the potential impact of agro-tourism on local residents directly or indirectly, such as socio-economic impact on fishing (coastal) community (Hamzah, et al., 2011; Mohamed Shaffril, et al., 2015), and perception on sustainable development among stakeholders in Cameron Highlands (Mohd Ariffin, et al., 2014). Another related study examined the factors affecting farmers' agro-tourism involvement in Cameron Highlands (Kunasekaran et al., 2012).

This study aims at identifying the social impacts of agro-tourism on local urban residents in Cameron Highlands based on the experience and perception of respondents. 
PLANNING MALAYSIA

Journal of the Malaysia Institute of Planners (2017)

\section{LITERATURE REVIEW}

Agro-tourism is the business activities related to education, entertainment and production operations that drive traffic to agricultural, farm or garden (MARDI, 2012). Agro-tourism is similar to eco-tourism, but it is more focusing on the use of agricultural resources as tourist attractions. In this context, the tourists have the opportunity to learn how to farm as well as on the lives of local farmers and cultural exchanges that occurs (Por, 2001).

Tourism activities and developments are related to various potential impacts. In term of social-economic, Lickorish (1994), Bott-Alama (2003) and Mason (2008) relate tourism to the positive impacts, i.e. creation of employment, an increase of revenues/income, a creation of job opportunities, development of craft industries, and regional development. For instance, Bott-Alama (2003) found that in Poland, non-agricultural income (i.e. from agro-tourism) was growing faster than agricultural incomes due to the development of rural tourism. On the opposite end, tourism has also raised negative impacts on the society such as inflation and over-dependence on tourism (Pearce, 1987; Mason, 1995). The inflation relates to the increase in the price of land, houses and food that occurs as a result of tourism development. Meanwhile, over-dependence on tourism occurs when the local people are mostly engaged in tourism and related industries.

Other social impacts of tourism on local community include the rebirth of local arts and craft and traditional cultural activities, the revival of social and cultural life, the renewal of local architectural traditions, modification to the way of life and to adapt other culture, limiting migration and commutation, and maintenance of younger population in an area due to the availability of more jobs in the agricultural/rural area (Mason, 1995; Burny, 2008).

\section{RESEARCH METHODOLOGY}

\section{Scope of Study}

This study focussed on the social impact of agro-tourism activities and development on selected social aspects of the community, which are safety, vandalism, employment and business opportunity, competition, migration, culture, language, and social/religious values. The impacts were based on the perception and experience of local urban residents.

\section{Study Area}

Cameron Highlands was chosen as the study area. Cameron Highlands is located at the west of Pahang state (Figure 1). Its boundary touches part of Kelantan at the north, and it shares part of its border with Perak. Cameron Highlands is approximately $90 \mathrm{~km}$ from Ipoh and about $200 \mathrm{~km}$ from Kuala Lumpur. There are 
Oliver Ling Hoon Leh, Mohd Hafizol, Marlyana Azyyati, \& Siti Nur Afiqah

Social Impact of Agro-Tourism on Local Urban Residents. Case Study: Cameron Highlands, Malaysia

three major road networks that connect Cameron Highlands with the surrounding districts.

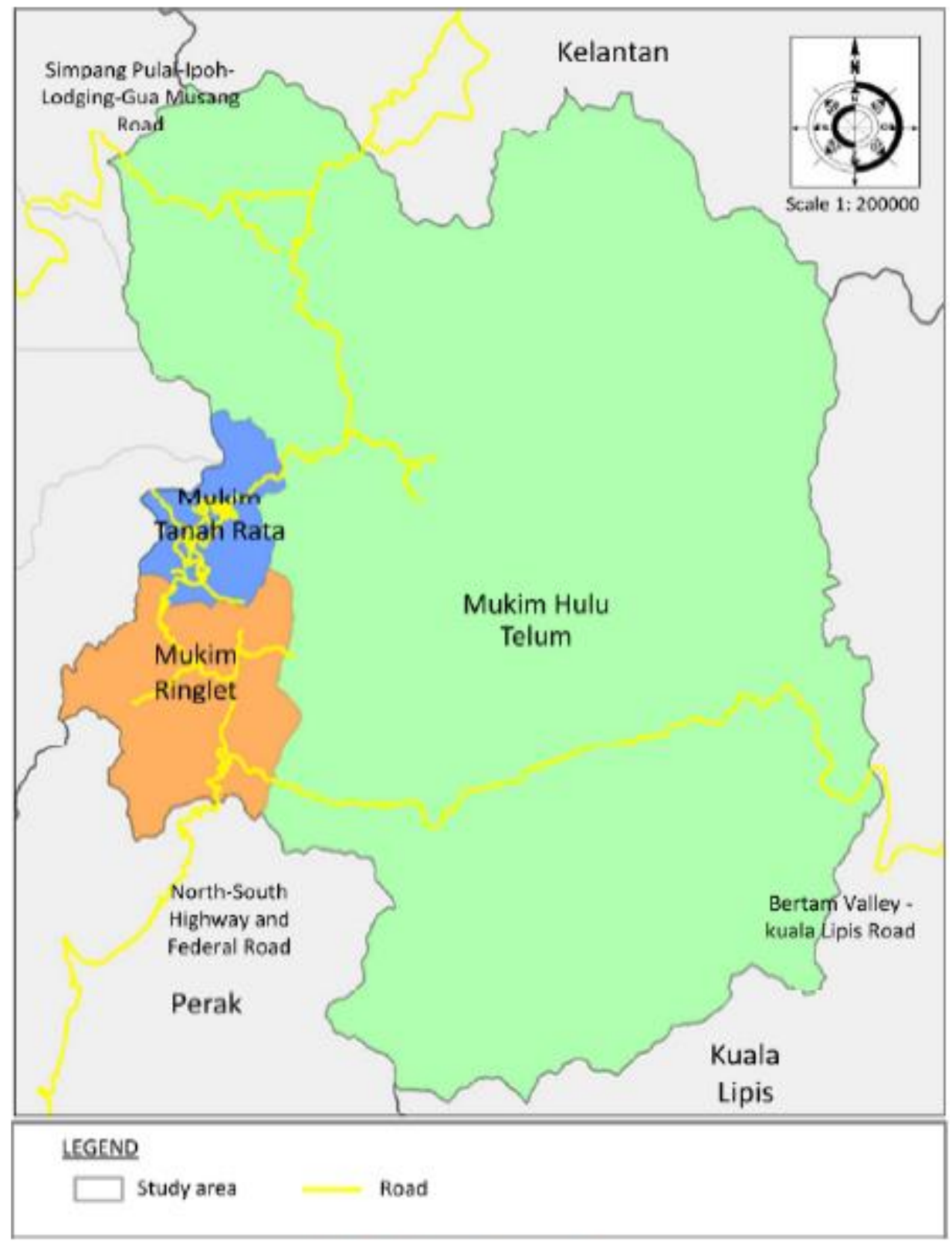

Figure 1 Cameron Highlands Sub-districts Source: Cameron Highland District Council, 2014 


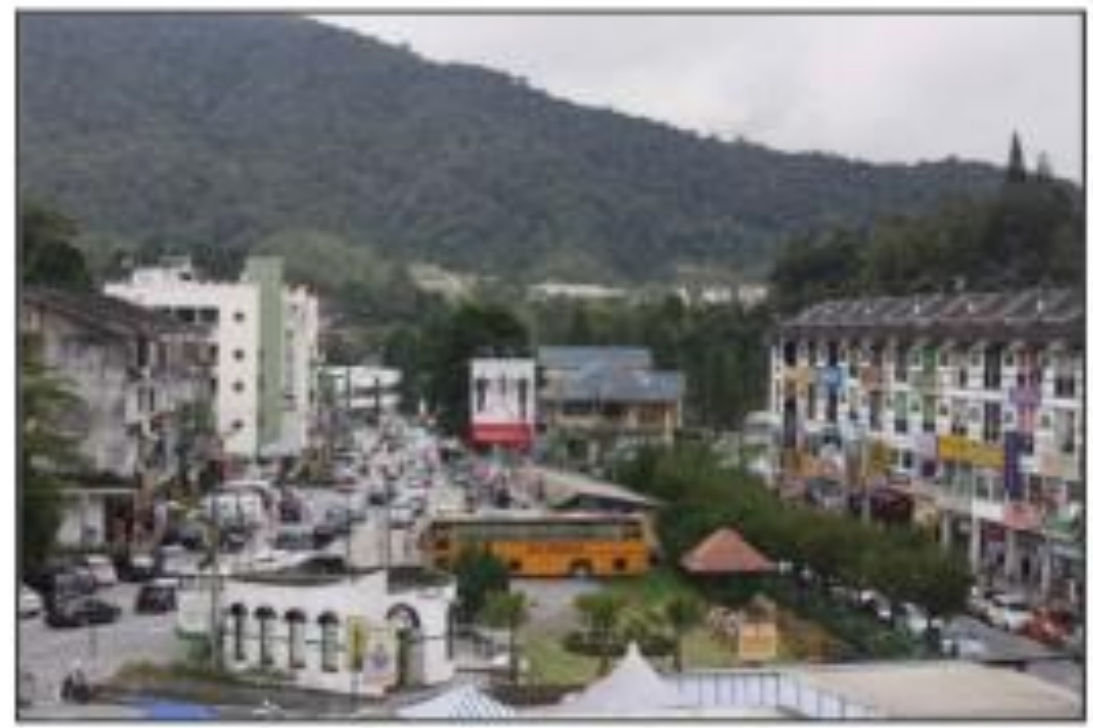

Photo 1 Tanah Rata - one of the urban settlements in Cameron Highlands

Cameron Highlands is made up of three sub-districts (mukim), namely Ulu Telum, Tanah Rata and Ringlet. However, this study only focussed on Tanah Rata, which is the most urbanised area in Cameron Highlands. Sample of respondents were selected from the three main urban areas in the sub-district, i.e. Tanah Rata, Brinchang and Kea Farm (Table 1).

The existing land use in Cameron Highlands includes forest, agriculture, commerce, housing, recreational area and public facilities. The built-up in Cameron Highlands covers an area of 1,047.28 hectares or 1.47 percent of the total district. The built-up areas are located along the main road such as in Ringlet, Bertam Valley Habu, Tanah Rata, Brinchang, Kea Farm, Tringkap, Kuala Terla and Kampung Raja.

On the other hand, the 70,170 hectares of non-built-up areas, or 98.5 percent of the total district, is dominated by forested areas $(90.18 \%)$, and followed by agriculture $(8.32 \%)$. Some of the famous spots of agro-tourism in Cameron Highlands are Cactus Valley at Brinchang, Boh Tea farm, strawberry farms, vegetable farms, nurseries, honey outlets, and others.

\section{Questionnaire Survey and Sampling of Respondents}

The questionnaire survey was divided into two sections as follows:

a) Background of respondents, i.e. gender, age, ethnic, religious, income, education, employment, and duration of stay.

b) Potential social impacts on selected aspects i.e. safety, vandalism, employment and business opportunity, competition, migration, culture, 
Oliver Ling Hoon Leh, Mohd Hafizol, Marlyana Azyyati, \& Siti Nur Afiqah

Social Impact of Agro-Tourism on Local Urban Residents. Case Study: Cameron Highlands, Malaysia

language, and social/religious values. Respondents were required to give their opinion on the impact for the current state and the past five (5) years during the questionnaire interview survey.

A sample of 100 respondents were selected in the study area. Table 1 showed the distribution of respondents and population size at the three selected urban settlements, i.e. Tanah Rata, Brinchang and Kea Farm. The respondents were chosen using stratified sampling technique that the probability of a sample of the population to be selected is same for the three settlements. The sample covers residents both male and female, and various socio-economic backgrounds above the age of 17 years old. In general, the majority of the respondents (85\%) stayed at Cameron Highlands more than 10 years. Most of them (80\%) are engaged in tourism and agricultural sectors. The background of respondents is as shown in Table 2.

Table 1 Population Size and Samples for Questionnaire Survey in Study Area

\begin{tabular}{lcccc}
\hline Sub-district & $\begin{array}{c}\text { Population } \\
(\text { nos.) }\end{array}$ & $\begin{array}{c}\text { Population } \\
\text { percentage }(\%)\end{array}$ & $\begin{array}{c}\text { Sample } \\
(\text { nos.) }\end{array}$ & $\begin{array}{c}\text { Percentage } \\
(\%)\end{array}$ \\
\hline Tanah Rata & 5,708 & 49.5 & 49 & 49.0 \\
Brinchang & 3,915 & 33.9 & 34 & 34.0 \\
Kea Farm & 1,911 & 16.3 & 17 & 17.3 \\
\hline Total & 11,534 & 100.0 & 100 & 100.0 \\
\hline
\end{tabular}

*Note: size of population in year 2010 (JPBD, 2014)

\section{Method of Analysis}

The perception of respondents on the impacts of agro-tourism was analysed by comparing their perception on the current state with the previous five years. The five-year period was used to indicate the impact of agro-tourism over a period of time. The data were analysed using Frequency and Cross-tabulation tests as available in Statistical Package for Social Science (SPSS) software.

Table 2 Background of Respondents

\begin{tabular}{lc}
\hline Variables & Percentage $(\%)$ \\
\hline Gender & \\
\hline Male & 62.0 \\
Female & 38.0 \\
\hline Age & \\
\hline $18-29$ years old & 25.0 \\
$30-44$ years old & 23.0 \\
$45-54$ years old & 38.0 \\
$55-64$ years old & 12.0 \\
65 years old and above & 2.0 \\
\hline
\end{tabular}

\section{Ethnic}


PLANNING MALAYSIA

Journal of the Malaysia Institute of Planners (2017)

\begin{tabular}{lc}
\hline Malay & 59.0 \\
Chinese & 15.0 \\
Indian & 21.0 \\
Others & 5.0 \\
\hline Religious & 59.0 \\
\hline Muslim & 41.0 \\
Non-Muslim & \\
\hline Monthly Income & 39.0 \\
\hline RM 1500 \& below & 42.0 \\
RM 1501-3000 & 15.0 \\
RM 3001-4500 & 2.0 \\
RM 4501 -6000 & 1.0 \\
RM 6001 -7500 & 1.0 \\
RM 7501 \& above & \\
\hline Duration of Stay & 0.0 \\
\hline <1 year & 7.0 \\
1-3 years & 8.0 \\
3-10 years & 35.0 \\
11-30 years & 47.0 \\
31-60 years & 3.0 \\
\hline 60 years & 53.0 \\
\hline Employment & 27.0 \\
\hline Tourism sector & 20.0 \\
Agricultural sector & 3.0 \\
Others & 2.0 \\
\hline Education & 38.0 \\
\hline No formal schooling & 30.0 \\
Lrimary school & \\
Higher secondary school & \\
Pre-university \& higher education & \\
\hline
\end{tabular}


Oliver Ling Hoon Leh, Mohd Hafizol, Marlyana Azyyati, \& Siti Nur Afiqah

Social Impact of Agro-Tourism on Local Urban Residents. Case Study: Cameron Highlands, Malaysia

\section{FINDINGS}

\section{Positive Impact: Increase in Employment Opportunity and Income for Locals}

Based on the perception of respondents, the majority $(74 \%)$ of the respondents disagreed or strongly disagreed that for the past 5 years, agro-tourism activities had increased employment opportunities and income for the locals (Table 3). However, currently (year 2014), the majority (84\%) of respondents agreed or strongly agreed that agro-tourism activities has increased the employment opportunities and income for them. The findings showed that agro-tourism activities were positively affecting the local residents by increasing the employment opportunities and income.

According to the respondents, the agro-tourism activities have attracted the local and foreign tourists in coming to Cameron Highlands especially during school holidays. Through the arrival of the tourists, many job opportunities were made available to local residents such as working in the hotel, working as traveller's guide, selling souvenirs and agricultural products (e.g. corn, strawberries, sweet potatoes, tea, flowers and others). According to respondents, these job opportunities help in reducing the unemployment rate in the study area and indirectly increase the living standard of the communities.

Table 3 Impact of Agro-Tourism on Increased Employment Opportunities and Income

\begin{tabular}{lcc}
\hline Perception & \multicolumn{2}{c}{$\%$ of respondents } \\
\cline { 2 - 3 } & $\begin{array}{c}\text { Perception for the past } \\
\text { 5 years }\end{array}$ & $\begin{array}{c}\text { Perception for the current } \\
\text { state (2014) }\end{array}$ \\
\hline Strongly disagree & 29 & 4 \\
Disagree & 45 & 7 \\
Neutral & 10 & 5 \\
Agree & 9 & 57 \\
Strongly agree & 7 & 27 \\
\hline Total & 100 & 100 \\
\hline
\end{tabular}

\section{Positive Impact: Increase in Local Product Demand}

Currently, the majority (93\%) of respondents agreed or strongly agreed that agrotourism activities has increased the demand for local products. The marketable local products included souvenirs, plants, tea products, fruits (e.g. strawberries), flowers, and vegetables (Table 4). Due to the tourism activities, local products have been easily marketed to local and foreign tourists. However, $17 \%$ of respondents felt that the positive impact was already there five years ago. It showed a clear increment of the market (demand) for local tourism and products due to the agro-tourism activities in the study area over these five years period. The increasing number of workers due to the agricultural development in the 
PLANNING MALAYSIA

Journal of the Malaysia Institute of Planners (2017)

study area has also expanded the market for local products and businesses, especially the retail shops.

Table 4 Impact of Agro-Tourism on the Increase in Local Products Demand

\begin{tabular}{lcc}
\hline Perception & \multicolumn{2}{c}{$\%$ of respondents } \\
\cline { 2 - 3 } & $\begin{array}{c}\text { Perception for the past } \\
\text { 5 years }\end{array}$ & $\begin{array}{c}\text { Perception for the current } \\
\text { state }(2014)\end{array}$ \\
\hline Strongly disagree & 47 & 0 \\
Disagree & 25 & 0 \\
Neutral & 11 & 7 \\
Agree & 9 & 25 \\
Strongly agree & 8 & 68 \\
\hline Total & 100 & 100 \\
\hline
\end{tabular}

Positive Impact: Increase of Business Opportunities in Tourism and Related Industries

Currently, the majority of respondents (93\%) agreed or strongly agreed that agrotourism has increased the business opportunities in tourism and related industries. Only $9 \%$ of respondents agreed or strongly agreed that this impact was already seen in the last 5 years. According to the respondents, tourism industry has increased business opportunities for local residents. Locals are providing various types of tourism services such as hotels, rest houses, motels, home stays restaurants, petrol station, shops, money exchangers and travel agencies. In terms of employment, the majority of respondents (53\%) are working in the tourism sector as compared to $27 \%$ in the agricultural sector (Table 2). To support agrotourism, government, especially, Cameron Highlands District Council is providing infrastructure to tourists such as Tanah Rata Bus Stations, and sites for night market and food stalls.

\section{Positive Impact: Increase of In-migration}

The agro-tourism activities in the study area has also successfully attracted inmigration due to the availability of job opportunity as well as business opportunity in the study area. $81 \%$ of respondents agreed/strongly agreed that the agro-tourism activities has increased in-migration (Table 5). However, only $18 \%$ of respondents who agreed/strongly agreed that the agro-tourism activities has increased in-migration in the last 5 years. This shows that more people migrated to the study area recently. 
Oliver Ling Hoon Leh, Mohd Hafizol, Marlyana Azyyati, \& Siti Nur Afiqah

Social Impact of Agro-Tourism on Local Urban Residents. Case Study: Cameron Highlands, Malaysia

Table 5 Impact of Agro-Tourism on the Increase of In-migration

\begin{tabular}{lcc}
\hline Perception & \multicolumn{2}{c}{$\%$ of respondents } \\
\cline { 2 - 3 } & $\begin{array}{c}\text { Perception for the } \\
\text { past 5 years }\end{array}$ & $\begin{array}{c}\text { Perception for the } \\
\text { current state (2014) }\end{array}$ \\
\hline Strongly disagree & 26 & 5 \\
Disagree & 55 & 2 \\
Neutral & 1 & 12 \\
Agree & 10 & 57 \\
Strongly agree & 8 & 24 \\
\hline Total & 100 & 100 \\
\hline
\end{tabular}

Data on the respondents' place of origin (Table 6) showed that $38 \%$ of respondents migrated either from other districts in Pahang or other states. Based on the data of Department of Statistics (DOS, 2014), from the total population of 36,978 in Cameron Highlands (in the year 2010) 5,380 were immigrants. The inmigration has led to increased population of the study area. The total population of Cameron Highland district in 2000 was only 30,495 (Brinkhoff, 2013).

Table 6 The origin of respondents

\begin{tabular}{lc}
\hline Area of origin & $\%$ of respondents \\
\hline Sub-district of Tanah Rata (study area) & 61 \\
Other sub-districts in Cameron Highlands & 1 \\
Other districts in Pahang & 20 \\
Other states & 18 \\
\hline Total & 100 \\
\hline
\end{tabular}

\section{Positive Impact: Able to Interact, Communicate and Learn Foreign Language with Tourists}

$82 \%$ of respondents agreed or strongly agreed that the development of agrotourism in the study area has created more opportunities for local residents to interact and communicate with tourists, and learning a foreign language from tourists. There were only $27 \%$ of respondents agreed/strongly agreed that this impact was already evident for the past 5 years. According to respondents, the common language used for them to communicate with foreign tourists is English. Thus, agro-tourism development has increased their opportunity to practice English and further improved their communication skill. 
PLANNING MALAYSIA

Journal of the Malaysia Institute of Planners (2017)

Table 7 Impact of Agro-Tourism on the Increase of Crime

\begin{tabular}{lcc}
\hline Perception & \multicolumn{2}{c}{$\%$ of respondents } \\
\cline { 2 - 3 } & $\begin{array}{c}\text { Perception for the past } \\
\text { 5 years }\end{array}$ & $\begin{array}{c}\text { Perception for the current } \\
\text { state }(2014)\end{array}$ \\
\hline Strongly disagree & 24 & 5 \\
Disagree & 57 & 5 \\
Neutral & 12 & 9 \\
Agree & 2 & 64 \\
Strongly agree & 5 & 17 \\
\hline Total & 100 & 100 \\
\hline
\end{tabular}

\section{Negative Impact: Increased Perception of Crime and Safety}

Majority of the respondents (81\%) agreed or strongly agreed that agro-tourism activities has increased the crime rate in the study area (Table 7). When compared to the past 5 years, only $7 \%$ of respondents felt that has already on the increase due to agro-tourism activities in the study area. Motorcycle theft was one of the main contributors to increased crime rate in the study area (Mohd Atar, 2013). Respondents perceived the increased in crime rate is partly due to the influx of foreign workers who worked at the farm and the tourism related businesses. In fact, the Malaysian Immigration Department has conducted several operations to arrest illegal foreign workers in Cameron Highlands (Sayed Idris, 2014).

In terms of fear of crime, $79 \%$ of the respondents agreed or strongly agreed that they now feel unsafe as a result of growth in agro-tourism in the area (Table $8)$.

Table 8 Impact of Agro-Tourism on the Fear of Crime due to Increased Crime Rate

\begin{tabular}{lcc}
\hline Perception & \multicolumn{2}{c}{$\%$ of respondents } \\
\cline { 2 - 3 } & $\begin{array}{c}\text { Perception for the past 5 } \\
\text { years }\end{array}$ & $\begin{array}{c}\text { Perception for the current } \\
\text { state (2014) }\end{array}$ \\
\hline Strongly disagree & 24 & 6 \\
Disagree & 55 & 3 \\
Neutral & 9 & 12 \\
Agree & 8 & 51 \\
Strongly agree & 4 & 28 \\
\hline Total & 100 & 100 \\
\hline
\end{tabular}

\section{Negative Impact: Increased Vandalism}

The majority of respondents (86\%) agreed or strongly agreed that agro-tourism activities has caused an increase in vandalism in the study area. However, only $22 \%$ of respondents agreed or strongly agreed that agro-tourism has caused increase in vandalism in the past 5 years. It showed that the issue of vandalism activities has increased in the study area due to the agro-tourism activities. 
Oliver Ling Hoon Leh, Mohd Hafizol, Marlyana Azyyati, \& Siti Nur Afiqah

Social Impact of Agro-Tourism on Local Urban Residents. Case Study: Cameron Highlands, Malaysia

\section{Negative Impact: Competition from Foreign Workers}

Agro-tourism activities had increased the employment opportunities to local residents (Table 3), but also increased their job competition with foreign workers. $89 \%$ of respondents agreed or strongly agreed that, as a result of agro-tourism development, currently locals have to compete with foreign workers for jobs in the study area. On the other hand, only $19 \%$ of respondents agreed or strongly agreed that job competition between locals and foreign workers has been on the increased in the past 5 years as a result of agro-tourism growth. Foreign workers in Cameron Highlands were often employed at lower wages. The competition for jobs between local and foreign workers might lead to reduced wages for locals as well. Additionally, Utusan Online (2014) reported that some foreign workers were also running their own businesses in Cameron Highlands illegally.

\section{Negative Impact: Deterioration of Local Language, Culture and Social Values}

One of the potential negative impacts of agro-tourism is the deterioration of local language, culture, and social values. The majority (74\%) of respondents agreed or strongly agreed that currently the deterioration in local language and religious values was the result of agro-tourism development in the study area (Table 9). Meanwhile, $79 \%$ of respondents also agreed or strongly agreed that the agrotourism activities contributed to conflicts in the local culture (Table 10). Such conflicts include consuming alcoholic drink, wearing revealing attire and promiscuous relationship.

Table 9 Impact of Agro-Tourism on Deterioration of Local Language and Religious

\begin{tabular}{|c|c|c|}
\hline & Values & \\
\hline \multirow[t]{2}{*}{ Perception } & \multicolumn{2}{|c|}{$\%$ of respondents } \\
\hline & $\begin{array}{c}\text { Perception for the } \\
\text { past } 5 \text { years }\end{array}$ & $\begin{array}{c}\text { Perception for the current } \\
\text { state (2014) }\end{array}$ \\
\hline Strongly disagree & 24 & 6 \\
\hline Disagree & 45 & 20 \\
\hline Neutral & 28 & 0 \\
\hline Agree & 3 & 48 \\
\hline Strongly agree & 0 & 26 \\
\hline Total & 100 & 100 \\
\hline
\end{tabular}


PLANNING MALAYSIA

Journal of the Malaysia Institute of Planners (2017)

Table 10 Impact of Agro-Tourism on Conflicts to Local Culture

\begin{tabular}{lcc}
\hline Perception & \multicolumn{2}{c}{$\%$ of respondents } \\
\cline { 2 - 3 } & $\begin{array}{c}\text { Perception for the past } \\
\text { Perception for the } \\
\text { Strongly disagree }\end{array}$ & $\begin{array}{c}\text { Pears } \\
\text { current state (2014) }\end{array}$ \\
Disagree & $\mathbf{2 4}$ & 1 \\
Neutral & $\mathbf{4 7}$ & 6 \\
Agree & 8 & 14 \\
Strongly agree & 16 & $\mathbf{5 1}$ \\
Total & 5 & $\mathbf{2 8}$ \\
\hline
\end{tabular}

\section{Negative Impact: Safety Risk due to Environmental Disaster}

Majority (88\%) of respondents agreed or strongly agreed that the agro-tourism has a negative impact on the environment that threatens the safety of people (Table 11). To compare, only $16 \%$ of respondents agreed or strongly agreed that the negative impact was there in the past 5 years. Due to indiscriminate forest clearing in Cameron Highland, the area has suffered environmental disasters such as landslides, flash floods and mud floods which threatened the lives and properties of the residents. Mud floods in Cameron Highlands have also claimed lives before (Berita Harian, 2013).

Table 11 Impact of Agro-Tourism on Safety of People due to Environmental Disaster

\begin{tabular}{lcc}
\hline \multirow{1}{*}{ Perception } & \multicolumn{2}{c}{$\%$ of respondents } \\
\cline { 2 - 3 } & Perception for the past 5 years & $\begin{array}{c}\text { Perception for the current state } \\
(2014)\end{array}$ \\
\hline Strongly disagree & 29 & 4 \\
Disagree & 45 & 5 \\
Neutral & 10 & 3 \\
Agree & 9 & 25 \\
Strongly agree & 7 & 63 \\
\hline Total & 100 & 100 \\
\hline
\end{tabular}


Oliver Ling Hoon Leh, Mohd Hafizol, Marlyana Azyyati, \& Siti Nur Afiqah

Social Impact of Agro-Tourism on Local Urban Residents. Case Study: Cameron Highlands, Malaysia

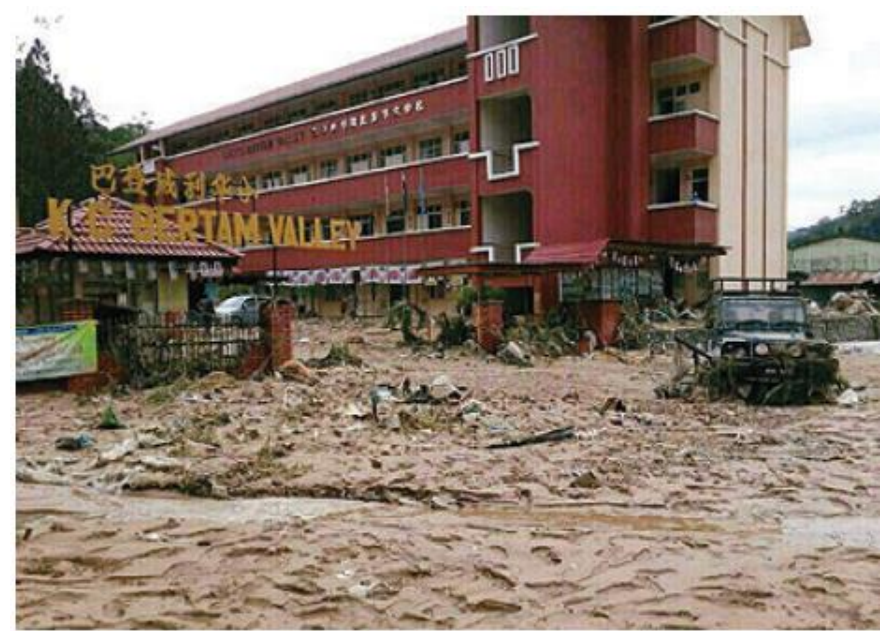

Photo 2 Flood in 2013 in Cameron Highlands

Source: Berita Harian (2013)

\section{CONCLUSION}

To conclude, agro-tourism development has impacted local urban residents in Cameron Highlands. For one, it attracted tourists into the area, which resulted in brisk businesses and more employment opportunities. It also increased migration into the study area, resulting in increased population number, but at the same time retaining existing residents from migrating out of the area. However, it also adversely impacted the population in the forms of increased crime rate, vandalism, environmental disasters and deterioration of local values and culture. Thus, promotion, implementation and expansion of agro-tourism in the study area must be accompanied by a well thought-out master plan and policies, not only to reap the benefits of the industry but also to minimise its adverse impacts on the population and the environment. 
PLANNING MALAYSIA

Journal of the Malaysia Institute of Planners (2017)

\section{ACKNOWLEDGEMENT}

The authors would like to thank Universiti Teknologi MARA (UiTM) for supporting the study. The authors would also like to thank all the government departments, organizations and individuals who had contributed to this study.

\section{REFERENCES}

Athanasopoulou, A. (2013). Tourism as a driver of economic growth and development in the EU-27 and ASEAN regions. Research Brief. The European Union Centre in Singapore.

Berita Harian (2013, October 23). Banjir di Cameron Highlands - 2 maut, seorang hilang. Berita Harian.

Bott-Alama, A. (2003, June). The economic and social benefits of rural tourism development in Poland. Seminar on Rural Tourism in Europe: Pathway to Sustainable Development, Kielce, Poland.

Brinkhoff, T. (2013). City population. Retrieved from www.citypopulation.de.

Burny, P. (2008). The economic, social and ecologic impact of the tourism in the Vatra Dornei Area. In Proceedings of the International Conference on Ecological Performance in a Competitive Economy (Volume II), Bucharest.

Cameron Highlands District Council (2014). Map of Cameron Highland.

Chou, M. C. (2013). Does tourism development promote economic growth in transition countries? A panel data analysis. Economic Modelling, 33, 226-232.

Department of Statistics [DOS] (2014). Migration and population distribution 2010. Putrajaya, Malaysia.

Economic Planning Unit [EPU] (2013). National Agrofood Policy (2011-2020), Prime Minister's Department, Putrajaya, Malaysia.

Federal Department of Town and Country Planning, Peninsular Malaysia [JPBD] (2014). Unpublished data on population of Cameron Highland.

Hamzah, A., Md. Yassin, S., Abu Samah, B., D’Silva, J. L., Tiraiyaei, N., Mohamed Shaffril, H. A., \& Uli, J. (2011). Socio-economic impact potential of agro tourism activities on Desa Wawasan Nelayan community living in Peninsular Malaysia. African Journal of Agricultural Research, 7(32), 4581-4588.

Kunasekaran, P., Ramachandran, S. Samdin, Z. \& Awang K. W., (2012). Factors affecting farmers' agro tourism involvement in Cameron Highlands, Pahang. OIDA International Journal of Sustainable Development, 4(1), 83-90.

Lickorish, J. L. (1994). Developing tourism destinations policies and perspectives. Harlow, Essex: Longman. 
Oliver Ling Hoon Leh, Mohd Hafizol, Marlyana Azyyati, \& Siti Nur Afiqah

Social Impact of Agro-Tourism on Local Urban Residents. Case Study: Cameron Highlands, Malaysia

Malaysian Agricultural Research and Development Institute [MARDI] (2012). Annual Report 2012, Malaysia.

Manzor, Z. (2009). Kesesakan jejas imej Cameron Highlands. Utusan Online. Retrieved

from http://ww1 .utusan.com.my/utusan/info.asp?y=2009\&dt=0110\&pub=Ut usan_Malaysia\&sec=Timur\&pg=wt_04.htm

Mason, P. (1995). Tourism: environment and development perspectives. United Kingdom. World Wide Fund for Nature.

Mason, P. (2008). Tourism impacts, planning and management. Oxford: Butterworth-Heinemann.

Mohamed Shaffril, H. A., Hamzah, A., Md. Yassin, S., Abu Samah, B., D’Silva, J.L., Tiraiyaei, N., \& Muhammad, M. (2015). The coastal community perception on the socio-economic impacts of agro-tourism activities in coastal villages in Malaysia. Asia Pacific Journal of Tourism Research, 20(3), 295-313.

Mohd Ariffin, A. R., Md Ali, Z., Zainol, R., Rahman, S., Ang, K. H. \& Sabran, N. (2014). Sustainable highland development through stakeholders' perceptions on agro eco-tourism in Cameron Highlands: a preliminary finding. SHS Web of Conferences 12. Retrieved from https://www.shsconferences.org/articles/shsconf/abs/2014/09/shsconf_4ictr2014_01086 /shsconf_4ictr2014_01086.html

Mohd Atar, N. (2013, March 11). Curi motosikal jenayah terancang. Sinar Harian. Retrieved from http://www.sinarharian.com.my/mobile/semasa/curi-motosikal-jenayahterancang-1.138371

Pearce, D. (1987). Tourism Development, $2^{\text {nd }}$ ed., Harlow: Longman Scientific and Technical.

Por, C. H. (2001). Unsur-unsur teori ekonomi. Kuala Lumpur: Fajar Bakti.

Risso, W. A., \& Brida, J. G. (2009). The contribution of tourism to economic growth: an empirical analysis for the case of Chile. European Journal of Tourism Research, 2(2), 178-185.

Sayed Idris, S. H. (2014, November 10). Imigresen gempur PATI di Cameron Highlands. Utusan Malaysia. Retrieved from http://www.utusan.com.my/berita/nasional/imigresen-gempur-pati8232-di-cameron-highlands-1.23027

Utusan Online (2014, November 7). Rasuah mungkin punca Cameron Highlands dipenuhi pendatang asing. Utusan Online. Retrieved from http://www.utusan.com.my/berita/nasional/rasuah-mungkin-puncacameron-8232-highlands-dipenuhi-pendatang-asing-1.21716.

Wojciechowska, J. (2014). A summary assessment of the agritourism experience in Poland. Revista de Turismoy Patrimonio Cultural, 12(3), 565-579. 